\title{
Determination of Microelements and Nutrition Ingredients of Jianghong Yulu
}

\author{
Ningli Qi ${ }^{1, a}$, Xiao Gong ${ }^{1, *, b}$, Xiaoli Yuan ${ }^{2, c}$, Chunliang Yang ${ }^{1, d}$ \\ ${ }^{1}$ Chinese Academy of Tropical Agricultural Sciences Center for Food Quality Supervision and \\ Testing Ministry of Agriculture (Zhanjiang), Zhanjiang, China \\ ${ }^{2}$ Chinese Academy of Tropical Agricultural Sciences South Subtropical Crops Research Institute, \\ Zhanjiang, China \\ aqiqi120518@163.com, ${ }^{\mathrm{b}} 42839221 @ q q . c o m,{ }^{\mathrm{c}}$ qiqi120518@163.com, ${ }^{\mathrm{d}}$ yiyesuifeng@126.com
}

Keywords: Jianghong yulu; microwave digestion; FAAS; microelements; nutrition ingredient.

Abstract. In this paper, our helpfully microelements to human body, including $\mathrm{Ca}, \mathrm{Cu}, \mathrm{Fe}$ and $\mathrm{Zn}$ in Jianghong yulu are determined by FAAS. Besides, the nutrition ingredients such as moisture content, body fat, total sugar and protein are also analyzed. The proposed analytical procedure is also quick, convenient and exact.

\section{Introduction}

Yulu, soy sauce, also known as fish sauce or aquaculture, aquatic condiment, One kind. It is low in fish or seafood processing waste as raw materials, Lee Enzyme with an enzyme itself contains fish and microorganisms in certain Fermentation conditions. The current production and consumption of the region's major fish sauce located in Southeast Asia, the eastern coast of China, Japan and northern Philippines. In Japan, fish sauce widely used in aquatic products processing system Products (such as fish cakes) and agricultural products processing (such as pickles, soup, and noodles Etc.); in Vietnam, fish sauce is an essential seasoning meal people; in Liaoning, Shandong, Jiangsu, Zhejiang, Fujian, Guangzhou and other places have fish sauce production, which is the most famous fish sauce Fuzhou, exported to 16 countries And regions

Jianghong yulu, Zhanjiang Suixi people's fish, is also known as Ju, its long history, is Jiang Hong specialty products, is also a major agricultural brand Suixi, Zhanjiang in the public good reputation, Jiang Hong is not an ordinary Jiang Hong fish gravy Lu, known locally as "fish Mackerels." It is the fresh fish of the northern Gulf Harengula halogenated had placed in porcelain by raw salt rub marinade, seal the bottle fermentation long, deep, man-made changes in temperature and other process ${ }^{[1]}$. Although cheap and easy to get raw materials prices, but after special treatment, nutrient-rich features distinguished ${ }^{[2]}$. Many poor children at home with a bottle of fish Mackerels healthy growth, the locals described it as "blood drops", which means health, nutritional status is very good. Quite a few of the elderly and disease due to Deficiency eat fish Mackerels collection for many years to health and longevity. The elderly and disease eat fish Mackerels collection for many years to health and longevity. Zhanjiang Suixi, Jianghong yulu is unique sauces, also known as Jianghong yulu, it is one of Zhanjiang Suixi popular salty condiment. Its taste delicious, unique flavor contains abundant nutrients.

With emphasis on food safety, security condiments such products are gradually coming into view, and trace metals Jianghong yulu is still no research, this study took Jiang Hong Suixi County, Jianghong yulu as research subjects, we are hoping to provide relevant basis for the development of river red sauce industry.

\section{MATERIALS AND METHODS}

\section{Instruments and materials}

BINDER electric oven thermostat blast; AA-160 electronic balance; CEM MARS microwave digestion system (CEM US company); Z-2000 atomic absorption spectrophotometer (Hitachi, Japan); zinc, calcium, iron, copper hollow cathode lamp. 
Jianghong yulu (available from Zhanjiang Suixi market); hydrochloric acid, ethanol, petroleum ether, zinc acetate, potassium ferrocyanide, anthrone reagent, citric acid, sodium chloride, sodium sulfate, potassium sulfate, sulfuric acid, boric acid, sodium hydroxide, hydrochloric acid, methylene blue, methyl red, silver nitrate, potassium chromate, nitrate, hydrogen peroxide (all analytical grade); ultra-pure water, sodium chloride, calcium, iron, copper, zinc and reference material.

\section{The experimental methods and conditions}

Instrument conditions shown in Table $1^{[3]}$

Table 1. The operating conditions of this experimental.

\section{Sample Preparation}

\begin{tabular}{cllll}
\hline Element & $\mathrm{Ca}$ & $\mathrm{Fe}$ & $\mathrm{Cu}$ & $\mathrm{Zn}$ \\
\hline Lamp current/mA & 3.0 & 3.0 & 4.0 & 6.0 \\
Wavelength/nm & 422.7 & 248.3 & 324.7 & 213.8 \\
Slit/nm & 0.2 & 0.1 & 0.2 & 0.38 \\
Air flow $(\mathrm{L} / \mathrm{mm})$ & 6.7 & 7.8 & 8.5 & 10 \\
Acetylene flow $(\mathrm{L} / \mathrm{mm})$ & 1.0 & 1.0 & 2.0 & 2.3 \\
Lamp height $/ \mathrm{mm}$ & 6.0 & 6.0 & 6.0 & 8.0 \\
\hline
\end{tabular}

Accurately weighed sample was pulverized uniformly $1.5 \mathrm{~g}$, in $50 \mathrm{~mL}$ conical flask, add concentrated $\mathrm{HNO}_{3} 10 \mathrm{~mL}$, sealed overnight, the next day add concentrated $\mathrm{HNO}_{3} 10 \mathrm{~mL}, \mathrm{HClO}_{4} 5 \mathrm{~mL}$, set a hot plate heated slowly digested yet, until the solution was colorless and transparent, nearly dry up. After cooling, transferred to a $25 \mathrm{~mL}$ volumetric flask with $4 \% \mathrm{HNO}_{3}$ to the mark, mixing spare.

All these texts fit in a frame which should not be changed (Width: Exactly $187 \mathrm{~mm}$ (7.36"); Height: Exactly $73 \mathrm{~mm}$ (2.87") from top margin; Lock anchor).

\section{Standard solution}

Standard stock solution: $\mathrm{Ca}, \mathrm{Fe}, \mathrm{Cu}, \mathrm{Zn}$ are the national standard solution at a concentration of 1.0 $\mathrm{mg} / \mathrm{mL}$, National Steel Materials Testing Center, Steel Research Institute.

Use concentration: $\mathrm{Ca}$ is $100 \mathrm{~g} / \mathrm{mL} ; \mathrm{Fe}, \mathrm{Cu}, \mathrm{Zn}$ are $50 \mathrm{~g} / \mathrm{mL}$.

\section{Standard series}

$\mathrm{Ca}(0.0,1.0,2.0,4.0,6.0,8.0 \mathrm{~g} / \mathrm{mL}), \mathrm{Fe}(0.0,0.5,1.0,2.0,4.0,6.0 \mathrm{~g} / \mathrm{mL}), \mathrm{Cu}(0.0,0.1,0.2,0.3,0.4$, $0.5 \mathrm{~g} / \mathrm{mL})$, and $\mathrm{Zn}(0.0,0.5,1.0,2.0,4.0,6.0 \mathrm{~g} / \mathrm{mL})$.

Table 1 instrument conditions were determined for each series of standard working solution. The standard curve obtained by the computer to calculate the regression equation and correlation coefficient. In the experimental selected range of concentrations of each element concentration and absorbance both showed a good linear relationship. Table 2 shows the regression equations and correlation coefficient.

Table 2 Regression equation and interrelated coefficient

\begin{tabular}{llc}
\hline Element & Regression equation & Interrelated coefficien \\
\hline $\mathrm{Ca}$ & $\mathrm{y}=0.042 \mathrm{x}+0.0035$ & 0.9986 \\
$\mathrm{Fe}$ & $\mathrm{y}=0.0418 \mathrm{x}+0.0085$ & 0.9961 \\
$\mathrm{Cu}$ & $\mathrm{y}=0.2111 \mathrm{x}+0.002$ & 0.9985 \\
$\mathrm{Zn}$ & $\mathrm{y}=0.0519 \mathrm{x}+0.0142$ & 0.9973 \\
\hline
\end{tabular}

\section{Determination of nutrients}

\section{Determination of moisture, use the direct drying method ${ }^{[4]}$,}

Calculated as follows: $\mathrm{X}=\frac{M_{2}-M_{1}}{W_{0}} \times 100 \%$

$\mathrm{X}$-- sample mass fraction of water $(\%)$; $\mathrm{W}_{0^{--}}$sample mass, $\mathrm{g} ; \mathrm{W}_{1^{--}}$dried sample and check weighing dish weight, $\mathrm{g}$; $\mathrm{W}_{2--}$ constant weight weighing dish and sample weight, $\mathrm{g}$.

Determination of fat, the choice of acid hydrolysis ${ }^{[5]}$; 
Calculated as follows: $\quad \mathrm{X}=\frac{m_{1}-m_{0}}{m_{2}} \times 100 \%$

X-- sample fat content (\%); $m_{1}$ - Reception quality bottles and fats $(\mathrm{g}) ; m_{0}$ - Receiving a bottle of quality $(\mathrm{g}) ; \mathrm{m}_{2}$ - Mass of the sample $(\mathrm{g})$.

Total sugar was measured by anthrone colorimetry ${ }^{[6]}$

The drying to constant weight of glucose $0.1 \mathrm{~g}$, volume detection and analysis at $80{ }^{\circ} \mathrm{C}$ oven for 86 to $100 \mathrm{~mL}$, removing $10 \mathrm{~mL}$, then set the volume to $100 \mathrm{~mL}$, to obtain $0.1 \mathrm{mg} / \mathrm{mL}$ glucose standard solution, were taken glucose standard solution $0,0.1,0.2,0.3,0.4,0.6,0.8 \mathrm{~mL}$, distilled water to a final volume of $1 \mathrm{~mL}$, anthrone reagent were added $5 \mathrm{~mL}$, after boiling water bath for $10 \mathrm{~min}$, measured at $620 \mathrm{~nm}$ wavelength. Ordinate absorbance value of each standard concentration $(\mathrm{g} / \mathrm{mL})$ as the abscissa, the standard curve was plotted. Determination of the amount of glucose standard solution in the concentration range of $10 \mathrm{~g} / \mathrm{mL} \sim 80 \mathrm{~g} / \mathrm{mL}$ has a good linear relationship, department regression equation is: $\mathrm{A}=0.0096 \mathrm{C}-0.0139$, the correlation coefficient $\mathrm{R} 2=0.9995$.

\section{Extraction and determination of total soluble sugar}

Accurately weighed $0.1 \mathrm{~g}$ of fish sauce, then add $50 \mathrm{~mL}$ mass fraction of $80 \%$ ethanol, $45^{\circ} \mathrm{C}$ constant temperature water bath $10 \mathrm{~min}$, after filtration, the filtrate $1 \mathrm{~mL}$, while distilled water as blank, an ice bath to cool reserve use. Jiang Hong sauce Determination of total soluble sugar content by the method of 1.2.1. Calculated as follows:

The total amount of sugar $($ glucose $)=\rho \times$ dilution factor $\times 10-4(\%)$, Where: $\rho$ sugar concentration from the standard curve obtained, $(\mathrm{g} / \mathrm{mL}) ; 10-4$ of the $\mathrm{g} / \mathrm{mL}$ in terms of percent coefficient.

\section{Determination of protein by Kjeldahl method ${ }^{[7]}$}

Weigh sample $0.1000 \sim 0.2000 \mathrm{~g}$ in $250 \mathrm{~mL}$ distillation tube, add $35 \mathrm{~mL}$ of distilled water swirling the sample dissolution, Nitrogen was added $1.0 \mathrm{~g}$ alloy, $7 \mathrm{~mL}$ of concentrated hydrochloric acid was placed in a distillation flask. Tecato a digestive apparatus. It was heated to $150{ }^{\circ} \mathrm{C}$. Remove the distillation tube to eliminate of the tube rack to cool to room temperature, the reaction $20 \mathrm{~min}$. Then add $10 \mathrm{~mL}$ concentrated sulfuric acid. Distillation tube is placed on the digestive system to digest at $480{ }^{\circ} \mathrm{C}$, until distillation tube clarified translucent white smoke of sulfuric acid and a small share taken after emerging Lower digestive tract and distillation tube rack to cool to room temperature in a fume hood. Together $10.20 \mathrm{~mL}$ of distilled water in the distillation tube at $100{ }^{\circ} \mathrm{C}$ continue to digest, to be remove the distillation tube distillation tube, the solution was clear and bright blue solution when cooled to room temperature, the automatic Kjeldahl distillation apparatus.

\section{Results and analysis}

\begin{tabular}{|c|c|c|}
\hline No. & Element & Content/mg/L \\
\hline \multirow{4}{*}{1} & $\mathrm{Ca}$ & $201.15 \pm 0.050$ \\
\hline & $\mathrm{Fe}$ & $8.57 \pm 0.009$ \\
\hline & $\mathrm{Cu}$ & $0.64 \pm 0.165$ \\
\hline & $\mathrm{Zn}$ & $5.87 \pm 0.347$ \\
\hline \multirow{4}{*}{2} & $\mathrm{Ca}$ & $180.05 \pm 0.241$ \\
\hline & $\mathrm{Fe}$ & $7.58 \pm 0.014$ \\
\hline & $\mathrm{Cu}$ & $0.57 \pm 0.215$ \\
\hline & $\mathrm{Zn}$ & $10.47 \pm 0.174$ \\
\hline \multirow{4}{*}{3} & $\mathrm{Ca}$ & $150.47 \pm 0.274$ \\
\hline & $\mathrm{Fe}$ & $8.17 \pm 0.412$ \\
\hline & $\mathrm{Cu}$ & $0.67 \pm 0.215$ \\
\hline & $\mathrm{Zn}$ & $15.23 \pm 1.241$ \\
\hline
\end{tabular}

\section{Part of nutrients}

Assay results of nutrients are shown in Table 4. 
Table 4 The content of nutrition ingredients in Jianghong yulu

\begin{tabular}{lllll}
\hline No. & Water & Fat & Total sugar & Protein \\
\hline \multirow{3}{*}{1} & 35.54 & 0.12 & 5.14 & 15.64 \\
& 32.78 & 0.15 & 3.16 & 18.79 \\
& 33.64 & 0.18 & 4.57 & 20.15 \\
2 & 30.45 & 0.24 & 6.12 & 20.18 \\
& 28.79 & 0.27 & 4.37 & 15.79 \\
& 32.87 & 0.17 & 5.16 & 13.68 \\
3 & 36.47 & 0.26 & 3.98 & 19.67 \\
& 35.67 & 0.34 & 4.08 & 17.34 \\
& 25.87 & 0.28 & 5.09 & 15.69 \\
\hline
\end{tabular}

\section{Conclusions}

The experimental results show generally high content of Ca sauce Hong Jiang, which may be its raw material (fish) concerned; and calcium is an essential element of the living body, plays an important role in the metabolism of a variety of whole cells, constitutes a wall and an important component of animal bones. Calcium deficiency can lead to dysplasia, short stature. Thus, Jianghong yulu is rich in calcium, iron, zinc and other metal elements beneficial. With in-depth study of, Jiang Hong industry will be further development.

China's total aquatic products has long been living in the world, by the end of 2015 the total amount of China's aquatic products has reached thousands of tons, of which freshwater fish production accounts for about 50 percent of the total, according to the by-products generated after its processing to head, fish bones, viscera, skin-based, these fish processing by-products in addition to some made of fish meal, fish dissolved pulp and other low-value products as feed for aquaculture, but most of the rest are discarded, easy to cause environmental pollution. Therefore, if the effective use of biological resources, such as processing waste microbial fermentation to develop a variety of useful physiological functions active natural products, you can enhance the utilization of fishery products, increase the added value of related industries, and to guide fisheries towards biological science and technology and modernization.

\section{Acknowledgements}

This work was financially supported by grants from the Fundamental Scientific Research Funds for Chinese Academy of Tropical Agricultural Sciences (Project No. 1630062015021).

\section{References}

[1] Hjalmarsson G H, Park J W, Kristbergsson K. Seasonal effects on the physicochemical characteristics of fish sacue made from capelin (Mallotus villosus) [J]. Food chemistry, 2007, 103(2): 495-504.

[2] Gan Hui. The traditional method of making several common aquatic flavoring [J]. Scientific Fish Farming, 2014(6): 76-77.

[3] Li X F, Ouyang Y Z, Zhang X X, Ouyang X. Flame atomic absorption spectrophotometry Pueraria 5 metal element content[J]. Applied Chemical Industry, 2015, 44(5): 963-966.

[4] Tang W. Determination of moisture and salinity of sea cucumber[J]. Science guide, 2015(21): 103 
[5] Wei Y Y, Guo M Y, Zhang L, Jiao T W. Acid hydrolysis determination of fat ham[J]. Meat industry, 2010(9): 21-22.

[6] Weng X, Xin G, Li Y X, Anthrone colorimetry potato starch, total sugar research[J]. Food Research and Development, 2013, 34(17): 86-88.

[7] Ye H L, Liu D, Ren W T. Semi-micro Kjeldahl method rapid determination of total nitrogen content in compound fertilizer[J]. Journal of Anhui Agricultural Sciences, 2015, 43(31): 28-29. 